\title{
Digital Learning Implementation Using Kahoot Application on Biotechnology of Plant in Mattayom 1
}

\author{
Rif'atul Fitri Supa'at ${ }^{1)}$, Erlia Narulita ${ }^{2)}$, Kanoklada ${ }^{3)}$ \\ ${ }^{1)}$ Student of Biology Education Study Program, Mathematics and Science Education Department, Faculty \\ of Teacher Training and Education. University of Jember \\ rifatulfitris@gmail.com \\ ${ }^{2)}$ Lecturer of Biology Education Study Program, Mathematics and Science Education Department, \\ Faculty of Teacher Training and Education. University of Jember \\ erlianarulita@gmail.com \\ ${ }^{3)}$ Biology Teacher of Hatyaiwittayalai Somboonkulkanya School, Thailand \\ Kanoklada@gmail.com
}

\begin{abstract}
Kahoot is a relatively new e-learning education tool.The data on its effectiveness in classroom teaching for plant biotechnology is scarce and limited. Hence the current research was aimed at incorporating Kahoot in classroom activity in plant biotechnology learning and to assess the effectiveness of Kahoot in the learning process. Qualitative research method was adopted in this study to investigate the applicability of the Kahoot!, the digital assessment tool, in Mattayom 1 ( ${ }^{\text {st }}$ Grade Junior High School). Using data collection methods such as qualitative research, observation, document analysis. There are 45 Participants from Mattayom 1/12 in Hatyaiwittayalaisomboonkulkannya School. Based on pre test and post test average value we can assessed effectiveness of Kahoot as an e-learning tool in Biotechnology learning. Pre test is assessment before using Kahoot. We can see that before we used Kahoot average value of test is 55,95 and after we used Kahoot average value of test is 81,92. Kahoot has made students' learning easy, enjoyable, and interactive and helped them to understand the subject better. Kahoot is an excellent e-learning tool that provides a positive environment in the classroom, increases energy, concentration, and knowledge. It can motivate the students to learn in a fun filled, enjoyable, and friendly competitive environment.
\end{abstract}

Key words: Kahoot, Digital learning, Assessment.

\section{INTRODUCTION}

The advance of technology use in schools has paralleled the advance of technology in our society. As these technological advances have made their way into our classrooms, the students have changed as well. The current group of students is unable to survive without their phones. It is a constant struggle in the classroom to have them put their phones away until the lesson or activity of the day is over.Despite this nearly ubiquitous access to computer technology, there is a significant gap between the presence of technology and its usage in the classroom (Wilkinson and Bere, 2016).

While many teachers still feel uncomfortable using technology in their teaching practice, it is also likely that teachers feel new technologies are unproven in the classroom (Rambe and Bere, 2013). Students today have a different profile of cognitive skills that resonate with digital tools. They expect multimedia, and they become quickly bored without it. Learning occurs based on students' engagement levels, and no doubt, students today are fascinated by digital devices. Leading educators agree that multisensory and multidimensional teaching methods are what engage student today and is easily achieved with digital programs (Ananth et al, 2018).

Talking about the use of digital games for learning is fast becoming a popular trend in educational technology. Hardly a week goes by without some professional periodical, magazine article, news item or television segment that makes mention of the educational potential of games. According to a recent study (Becker \& Jacobsen, 2005), approximately half of the teachers surveyed would be interested in trying games and simulations in class. (The number of teachers interested in using games is somewhat dependent on how the word 'game' is defined. When described as interactive simulations, the number is 
considerably higher than when the word 'game' is used) (Becker, 2007).

Learning-games help a student to improve his or her critical thinking skills, and acquire a more advanced level of education. Therefore, a higher quality of education results in a more satisfactory personal and academic achievement. Recently, electronic games have had a significant impact on children's lives. Hence, learning-games must combine more features to cater for more effective learning through technology (Aljojo, 2018).

Kahoot! is a game-based student response system (GBSRS), the application of which transforms the classroom into the format of a game show. Via a laptop or pc, the teacher presents questions on the classroom screen and students answer them by means of their mobile devices (Boden and Lindsay, 2018).

Kahoot, an emerging online education tool was appreciated by many educators worldwide and they have found that its incorporation in the classroom activity is quite effective in attracting the students' attention, motivating them to participate in classroom actively, helps in promoting their learning process and thereby enriching their knowledge and memory (Mohan et al, 2018).

Kahoot is a freely available online resource, easy to use, and simply requires multimedia tool such as cellphone, laptops, and chrome books to participate. Educators can create quizzes using MCQs and is presented in game-based formats to students (Siegle, 2015). Multiple choice questions (MCQs) can be developed to align with the learning objectives of the lecture topic such as basic principles, terminologies, diagnostic tests, clinical features, treatment and many other aspects. Furthermore, Kahoot quiz questions may also include multimedia visuals such as images and audio-visuals to evoke students' interest and promote their engagement in learning (Dellos, 2015).

Since March 2016, the Kahoot! Has been used by 20 million of 55 million American primary and secondary school students. The Kahoot! and similar applications are important elements in increasing students' cognitive capacity by offering differentiated learning experiences (Y1lmaz, 2017).

Underdal \& Sunde (2014) state that the Kahoot! plays an important role in gamification of the simple assessment programs and contributes to the success of the learners at different levels (as cited in Bolat, Simsek \& Ülker, 2017). In practice, background music, pictures and videos can be added; quizzes can be recorded and retrieved via Internet (Barnes, 2017). In the Kahoot! application, the teacher can select one of the options among quiz, discussion or questionnaire displayed under the heading "Create New Kahoot!" (Dellos \& Korea, 2015) by logging into his/her account. Besides, the scores can be obtained instantly with a teacher-controlled display in the classroom (Walsh, 2017). In addition, the quiz title is widely used in Kahoot! (Graham, 2015). Students can login the system with an access code and a username (Ismail \& Mohammad, 2017).

Kahoot is a relatively new elearning education tool and the research data on its effectiveness in classroom teaching about biotechnology for plant is scarce and limited. Hence the current research was aimed at incorporating Kahoot in classroom activity in plant biotechnology learning and to assess the effectiveness of Kahoot in the learning process.

\section{METHODOLOGY}

Qualitative research method was adopted in this study to investigate the applicability of the Kahoot!, the digital assessment tool, in Mattayom 1 ( $1^{\text {st }}$ Grade Junior High School). Using data collection methods such as qualitative research, observation, document analysis. There are 45 participants from Mattayom 1/12 in Hatyaiwittaya laisomboonkulkannya School. Prior to implementation, students would be given material about biotechnology for plant by power point. After explanation students were given pretest about Biotechnology. The function of pre-test is to know knowledge about biotechnology for plant for each students after explanation. By using Kahoot online resource (https://create.kahoot.it ), quizzes in the form multiple choice questions with 
four choices were prepared on selected lecture topics of Biotechnology of Plants. The questions were prepared to align with learning outcomes of the topics that were presented through PowerPoint presentation. Also students' response time for each question was set between 20 seconds to 30 seconds.

At the end of selected PowerPoint classroom lectures, students were asked to $\log$ in to Kahoot site through their smartphones. The students have to choose team game. Each team consists of 4 people. Once they $\log$ in to Kahoot site, it will show two columns; game pin and password. They type the same game pin on their electronic devices as displayed on the screen. They were allowed to use their own password to log into the particular session. One question with four options will be displayed on the classroom projector screen at a time. Only

Based on pre test and post test average value we can assessed effectiveness of Kahoot as an e-learning tool in Biotechnology learning. Pre test is assessment before using Kahoot. We can see that before we used Kahoot average value of test is 55,95 and after we used Kahoot average value of test is 81,92 . Based on Table 1 has shown that Kahoot in line with other game based online learning tools is very effective in motivating students and significantly enhances their learning by better engagement in the classroom. Students were more comfortable using Kahoot because there are pictures, audio and audio visual can make students more understand the aim of questions.

Using Kahoot make classroom was more fun because we are not only answer questions in paper but also we can see the ilustration of questions by picture or videos. Plump and LaRosa in their study on Kahoot found high rating of the activity by the students in terms of their classroom engagement and enhancement of learning process. They stated Kahoot has made students' learning easy, enjoyable, and interactive and helped them to understand the subject better (Plump and LaRosa, 2017). Use of visual images along with the questions evokes students' interest and the four (4) options will be shown in the students' smartphones. They need to look at the projector screen for the question and give their response by choosing one of the options displayed on their smartphones. After response time for each question closes, students responses were displayed on the projector screen in the form of a bar diagram. At the end of the session 3 top students, as displayed on the screen were awarded with chocolates to keep them motivated.

\section{RESULT AND DISCUSSION}

Student learning outcomes will be seen in pre test and post test average value (Table 1).

Table1. Pretest and Post test Score

\begin{tabular}{|c|c|}
\hline Pretest & Posttest \\
\hline 55,95 & 81,92 \\
\hline
\end{tabular}

concentration. Incorporating the music in the game entertains students. Kahoot also tackles kinesthetic of the students by keeping them physically active while answering questions displayed on the classroom projector screen.

A previous study has shown students' learning, performance, and achievement significantly increases if they are taught by using techniques and approaches aligned with their learning styles (Burke and Dunn, 2002).

Kahoot $^{\mathrm{TM}}$ was an effective pedagogical tool because the students found it fun and engaging. Students commented on how they enjoyed the competitive aspect of Kahoot $^{\mathrm{TM}}$. Students who preferred not to engage in the competitiveness could still participate as they could remain anonymous by using a fictitious screen name. Students were having fun and showing enthusiasm especially when seeing their screen names on the leaderboard. The energy level, engagement, and even class dialogue was observed higher if we use Kahoot. An interesting side effect to this was an increase use of peer study groups. Students in group were observed working together and supporting each other. Because students in the class were having fun with one another,

Bioedukasi Vol. XVI. No. 2 Oktober 2018 
starting conversations with one another appeared to be easier and less intimidating.

Kahoot has many advantages; freely available online, easy to use, multiple types of Kahoot are available (quizzes, discussions, surveys etc.), is compatible with smartphones, tablets, laptops, and ordinary computers, music and colors add to the students' excitement and concentration, and also the response time for answering each question is adjustable as per the students' needs. In addition, instructors can download and save the results for analysis and review of students' performance. No learning tool is without disadvantages. Similarly, Kahoot also has some disadvantages; MCQs can be prepared only with maximum four options, length of the stem is limited to 95 letters, it allows for only certain types questions such as single best choice, true or false, and its use always needs internet connection (Mohan et al, 2018).

\section{CONCLUSION}

Kahoot is an excellent e-learning tool that provides a positive environment in the classroom, increases energy, concentration, and knowledge. It can motivate the students to learn in a fun filled, enjoyable, and friendly competitive environment.

\section{REFERENCES}

Aljojo, N. 2018. The Design and Implementation of a Mathematics Game Base Learning Application for Primary Students. iJIM 12(3): 142-152.

Ananth N., Hamidah Hassan., Annamma.K., Amudha Pattabi. 2018. Implementation and evaluation of the online learning initiative: Towards a paperless classroom. International Journal of Healthcare Sciences 6(1): 199-206.

Barnes, R. 2017. Kahoot!! In the classroom: Student engagememt technique. Nurse Educator 42(6): 1.

Becker, K. \& Jacobsen, D. M. 2005. Games for learning: are schools ready for what's to come? DiGRA 2005 2nd International Conference, 'Changing
Views: Worlds in Play'. Vancouver, Canada: Digital Games Research Association.

Becker, K. 2007. Digital game-based learning once removed: Teaching teachers. British Journal of Educational Technology 38(3): 478488.

Boden, G.M., Lindsay H. 2018. Kahoot! game-based student response system. Journal of Learning and Teaching 11(1): 1-4.

Burke K, Dunn R. 2002. Learning stylebased teaching to raise minority student test scores there's no debate! The Clearing House 76(2):103-6.

Dellos R. 2015. Kahoot! A digital game resource for learning. International Journal of Instructional Technology and Distance Learning 12(4): 49-52.

Graham, K. 2015. TechMatters: Getting into Kahoot!!(s): Exploring a game-based learning system to enhance student learning. LOEX Quarterly 42(3): 4.

Ismail MA-A., Mohammad JA-M. 2017. Kahoot! a promising tool for formative assessment in medical education. Education in Medicine Journal 9(2):19-26.

Mohan BS., Vinod Nambiar., Rajeev Arvindakshan. 2018. Implementation and assessment of students' perception on effectiveness of kahoot game-based educational tool in learning microbiology. Journal of Biomedical and Pharmaceutical Research 7(4) 12-18.

Plump CM, LaRosa J. 2017. Using Kahoot! in the classroom to create engagement and active learning: a game-based technology solution for

Bioedukasi Vol. XVI. No. 2 Oktober 2018 
e learning novices. Management

Teaching Review 1-8.

Rambe P, Bere A. 2013. Using mobile instant messaging to leverage learner participation and transform pedagogy at a South African University of Technology. $B r J$ Educ Technol 44(4): 544-61.

Siegle D. 2015. Technology: Learning can be fun and games. Gifted Child Today. 38 (3): 192.

Walsh, R. 2017. Turning the smartphone into an EAP classroom learning device through Kahoot!! Eurocall 126-127.

Wilkinson K, Barter P. 2016. Do mobile learning devices enhance learning in Higher Education anatomy classrooms? J. Pedagog Dev. 6(1):14-23.

Yılmaz, M. B. 2017. Dijital Değerlendirme Araçlarının Ortaokul Öğrencilerinin Derse Bağl11ıklarına Etkisi: İki Farklı Okulda Durum. Abant İzzet Baysal Üniversitesi Eğitim Fakültesi Dergisi 17 (3): 16061620. 